\title{
Erratum to: UAE's Publishing Industry: A Vision of an Avant-Garde Nation
}

\section{Bodour Al Qasimi ${ }^{1}$}

\section{Erratum to: Pub Res Q \\ DOI 10.1007/s12109-016-9494-z}

In the original article, the author's name (Bodour Bint Sultan Al Qasimi) was included in the article title. The correct article title is given in this erratum. The original article was corrected.

The online version of the original article can be found under doi:10.1007/s12109-016-9494-z.

\section{Bodour Al Qasimi}

Bodour@kalimat.ae

1 Kalimat Publishing and Distribution, Post Office Box 21969, Sharjah, UAE 